\title{
Infrastructure Deficit, Financing Needs and the Post-2015 MDG Framework in Africa
}

\author{
Mthuli Ncube
}

\begin{abstract}
This article examines the infrastructure deficit and financing needs in Africa within the context of the Post-2015 Development Agenda. The article explains the extent of the infrastructure deficit across key categories and regions of Africa. The constraints and impact of the infrastructure deficit are discussed, especially the impact on productivity and growth. Innovative sources of funding are also discussed. The article shows the link between infrastructure development and poverty reduction, the current MDGs, and the post-2015 MDG agenda. The article concludes by arguing that an agenda for infrastructure development is coterminous with that of achieving the MDGs and poverty reduction.
\end{abstract}

\section{Introduction}

There is general acceptance that economic infrastructure is critical for economic growth and poverty reduction, given its pivotal role in improving competitiveness, facilitating both domestic and international trade and integration of the continent of Africa to the global economy. However, in Africa there is a large infrastructure deficit, both in terms of access and quality, to be filled in the sectors of transport, energy, information and communication technology (ICT) and water (Anyanwu and Erhijakpor 2009).

With less than two years before the Millennium Development Goals (MDGs) target date of 2015, development practitioners are already initiating consultations aimed at defining the contours of the Post-2015 Development Agenda. It has been widely recognised that the current MDGs focus excessively on the social aspect of the sustainable development agenda, neglecting the economic and environment ones. Current MDGs also de-emphasise productive sectors, including infrastructure. They are therefore not encouraging structural transformation. The next set of goals must address inequality and exclusion within a human development dimension and also tackle key sustainability challenges facing the world.
Infrastructure's importance for growth, poverty and achieving the MDGs has been recognised by the heads of state and government at the African Union meeting in Sirte, Libya, in July 2005 by deciding to include within the framework of the MDGs a transport target and indicators adopted in April 2005 by the African ministers responsible for transport and infrastructure with a view to speeding up poverty reduction, a fundamental objective of the international community. With adequate infrastructure, African firms could achieve productivity gains of up to 40 per cent (Escribano et al. 2008). And bringing Africa's infrastructure stock to the level of that of Mauritius could enhance Africa's GDP growth by as much as 2.2 per cent per year, according to the Africa Infrastructure Country Diagnostic (AICD) (Foster and BriceñoGarmendia 2010).

This article examines infrastructure development in Africa within the context of the Post-2015 Development Agenda. The remaining sections of the article are as follows. The next section examines the state of infrastructure access in the continent. Section 3 presents a snapshot view of the constraints on infrastructure development in Africa. Section 4 discusses innovative local sources of infrastructure finance in the continent, while 


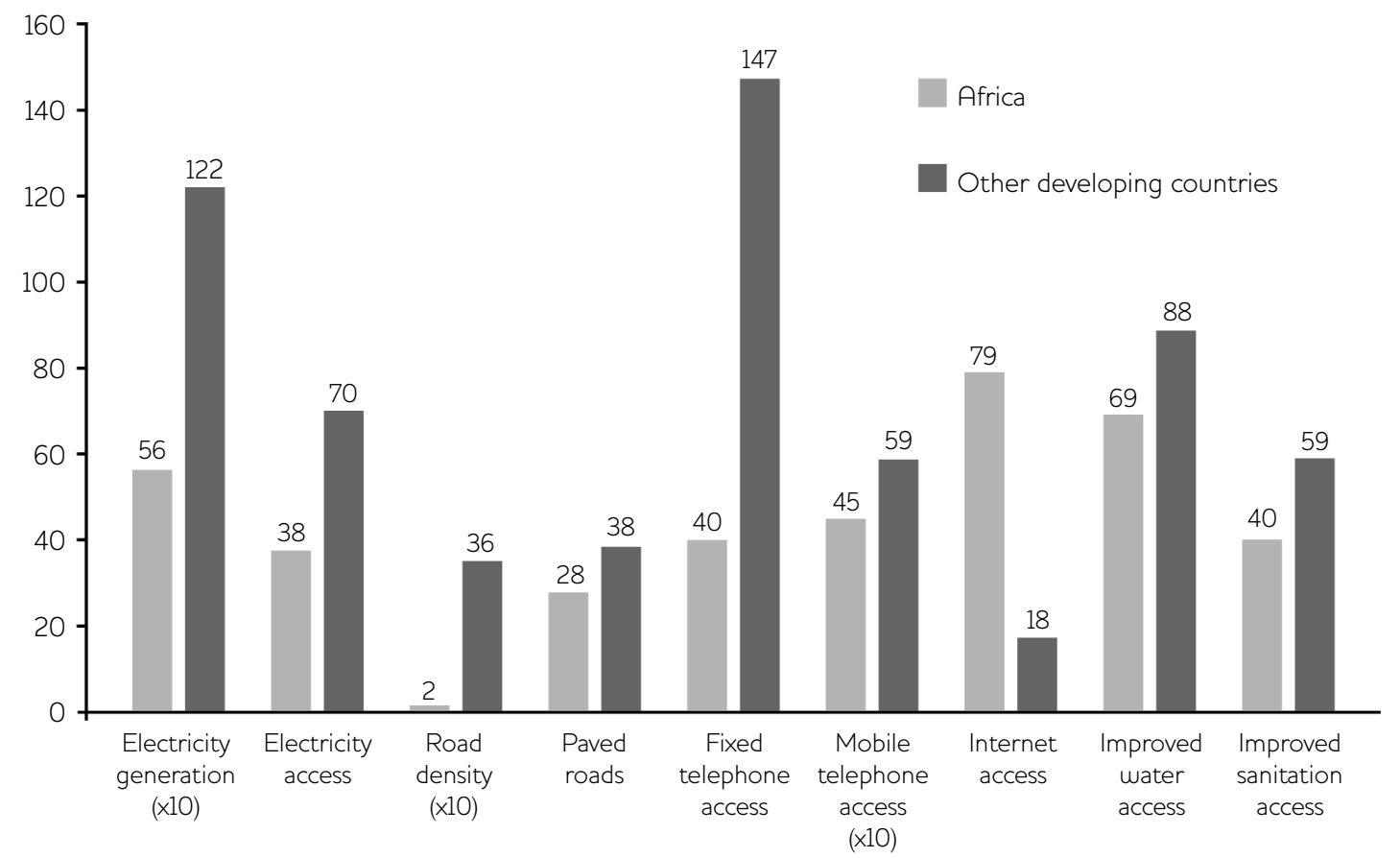

Note Electricity generation is measured in kilowatt hours per capita; road density in kilometres per 100 sq km of land; paved roads in percentage of total roads; electricity, improved water and improved sanitation access in population percentage; fixed telephone, mobile telephone and internet access in users per 1,000 people. Source Foster and Briceño-Garmendia (2010).

Section 5 examines infrastructure and poverty reduction and the post-2015 MDG framework. Section 6 concludes with the role of the African Development Bank (AfDB).

\section{State of infrastructure access in Africa $^{1}$}

Africa suffers from a critical shortage of infrastructure. Its infrastructure coverage lags behind other developing countries, particularly regarding access to electricity, transport networks, water and sanitation, irrigation, and ICT (Figure 1). Power deficits are the continent's biggest infrastructure challenge: per capita power generation is less than half the rest of the developing world's and declining. Not only has electricity access stagnated, but supply has also become less stable, with regular outages reported in at least 30 countries by 2007. Power outages are estimated to cost Africa between 1 and 2 per cent of GDP.

The AfDB's Africa Infrastructure Index, which ranks countries on the basis of electricity generation per capita, share of population with access to mobile or fixed phone line, percentage of roads paved and share of population with access to improved water and sanitation, illustrates the great diversity across Africa (Table 1).

There is wide variability in performance across 18 access, quality and cost dimensions. As may be expected, the infrastructure deficit in low-income countries is worse than in middle-income ones, and fragility further weighs on most dimensions.

The divide between rural and urban areas is generally even more pronounced. Access to improved water, for example, is almost twice as high in cities compared to rural areas (UN 2011). Only one in ten Africans living in rural areas have access to grid electricity, compared to well over 50 per cent of the urban population. Mobile phones, on the other hand, are shattering the isolation of rural areas, with one out of every two rural Africans now in range of a mobile signal. However, the cost of ICT services, including mobile telephony, remains high in Africa relative to other developing regions. 
Table 1 Africa Infrastructure Development Index and Country Ranking Score, 2010

\begin{tabular}{|c|c|c|c|c|c|c|c|c|}
\hline \multicolumn{2}{|c|}{ Rank Country } & \multirow{2}{*}{$\begin{array}{l}\text { Index } \\
100\end{array}$} & \multicolumn{2}{|c|}{ Rank Country } & \multirow{2}{*}{$\frac{\text { Index }}{31}$} & \multicolumn{2}{|c|}{ Rank Country } & \multirow{2}{*}{$\begin{array}{l}\text { Index } \\
20\end{array}$} \\
\hline 1 & Seychelles & & 19 & Malawi & & 37 & Nigeria & \\
\hline 2 & Mauritius & 90 & 20 & Zimbabue & 30 & 38 & Equatorial Guinea & 19 \\
\hline 3 & South Africa & 81 & 21 & Guinea & 29 & 39 & Mali & 18 \\
\hline 4 & Libya & 80 & 22 & Mauritania & 29.4 & 40 & Burkina Faso & 18 \\
\hline 5 & Egypt & 80 & 23 & Zambia & 28.6 & 41 & Togo & 17 \\
\hline 6 & Tunisia & 77 & 24 & Congo, Rep. & 28.6 & 42 & Mozambique & 14 \\
\hline 7 & Algeria & 71 & 25 & Lesotho & 28.5 & 43 & Liberia & 13 \\
\hline 8 & Morocco & 59 & 26 & Cameroon & 28.0 & 44 & Tanzania & 12 \\
\hline 9 & Cape Verde & 58 & 27 & Ghana & 28 & 45 & Central African Republic & 12 \\
\hline 10 & Botswana & 57 & 28 & Côte d'lvoire & 27 & 46 & Eritrea & 11 \\
\hline 11 & Gambia, The & 49 & 29 & Uganda & 26 & 47 & Madagascar & 7 \\
\hline 12 & Gabon & 45 & 30 & Rwanda & 25 & 48 & Niger & 6 \\
\hline 13 & São Tome and Principé & 43 & 31 & Burundi & 24 & 49 & Chad & 5 \\
\hline 14 & Comoros & 43 & 32 & Angola & 24 & 50 & Sierra Leone & 5 \\
\hline 15 & Swaziland & 39 & 33 & Sudan & 21 & 51 & Congo, Dem. Rep. & 5 \\
\hline 16 & Namibia & 38 & 34 & Benin & 21 & 52 & Ethiopia & 4 \\
\hline 17 & Djibouti & 37 & 35 & Guinea-Bissau & 21 & 53 & Somalia & - \\
\hline 18 & Senegal & 34 & 36 & Kenya & 20 & & & \\
\hline
\end{tabular}

Source AfDB (2011).

\section{Constraints to infrastructure development}

African countries face several constraints regarding infrastructure development and maintenance, including geographical constraints, deficiencies in planning, poor management of existing infrastructure assets, institutional inefficiencies and regulatory bottlenecks, demand-side constraints, and inadequate financing for project preparation and implementation.

The infrastructure deficit condemns Africa to perform below its economic potential. Power shortages, for example, cost the region 12.5 per cent in lost production time, compared to 7 per cent in South Asia (Figure 3). The shortage and poor quality of infrastructure, added to the lack of competition in service delivery, have also resulted in exorbitant connection and user costs when compared to other developing countries. Infrastructure services in Africa cost twice as much on average as in other developing regions and are exceptionally high by global standards.
Addressing the deficiencies in sub-Saharan Africa's infrastructure will require investments of about US $\$ 93$ billion per year. ${ }^{2}$ In most countries, infrastructure investment needs far exceed available public resources. Fragile states would require the equivalent of 37 per cent of their GDP per year, stable low-income countries 23 per cent of their GDP, and sub-Saharan middle-income countries the equivalent of 10 per cent of their GDP. While spending on Africa's infrastructure had swelled to US $\$ 45$ billion a year in 2008, the financing burden still falls disproportionately on government budgets, which shoulder 66 per cent of the expenditures, while the private sector covers 20 per cent and traditional development partners and emerging markets (i.e. fast-growing economies outside of the Organisation for Economic Co-operation and Development (OECD)) another 14 per cent.

\section{Financing infrastructure}

Financing for Africa's infrastructure has been predominantly from public resources. The public 
Figure 2 Access to infrastructure by income level and fragility

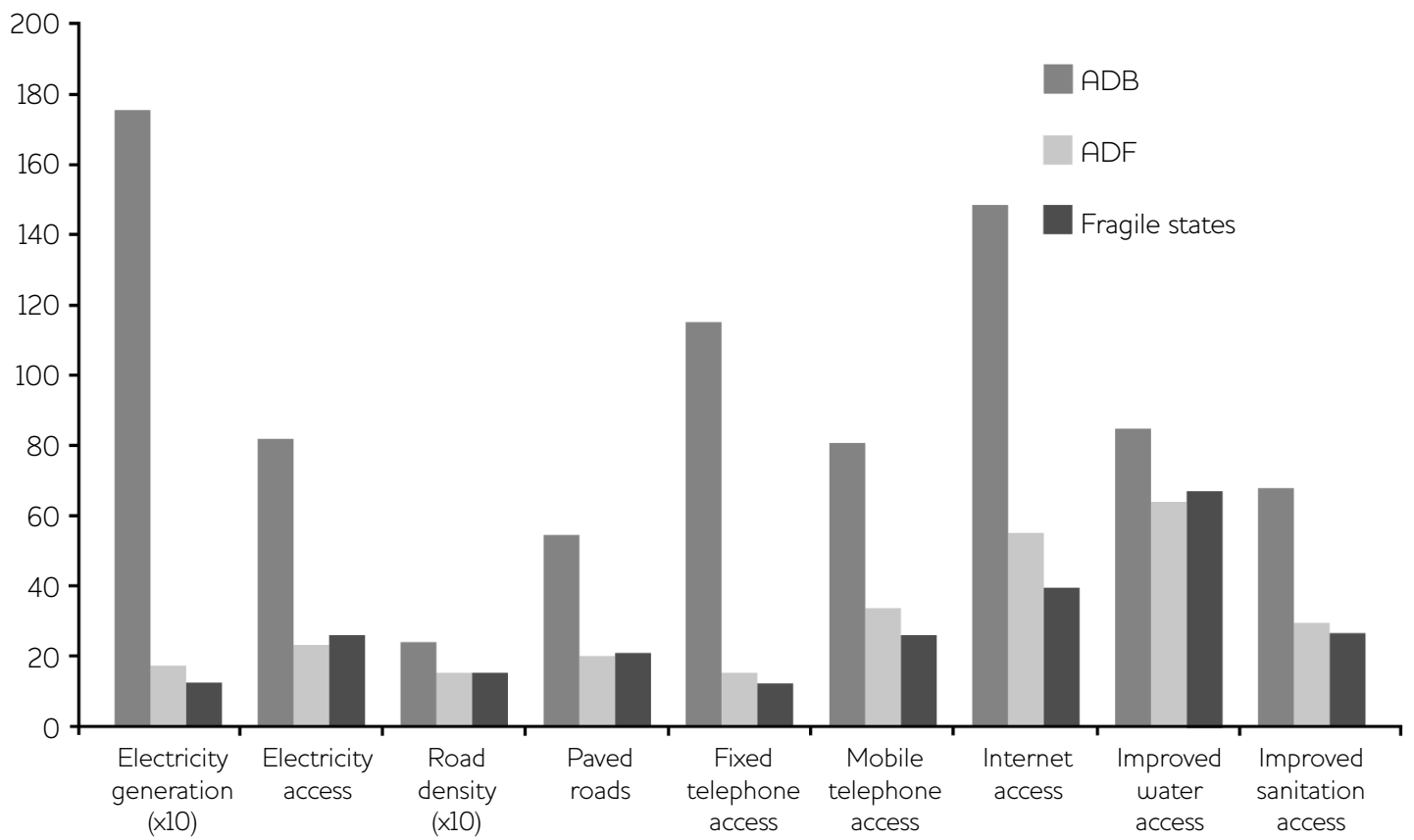

$(x 10)$

Note Electricity generation is measured in kilowatt hours per capita; road density in kilometres per 100 sq km of land; paved roads in percentage of total roads; electricity, improved water and improved sanitation access in population percentage; fixed telephone, mobile telephone and internet access in users per 1,000 people. Source Foster and Briceño-Garmendia (2010).

Figure 3 Productivity loss from power outages

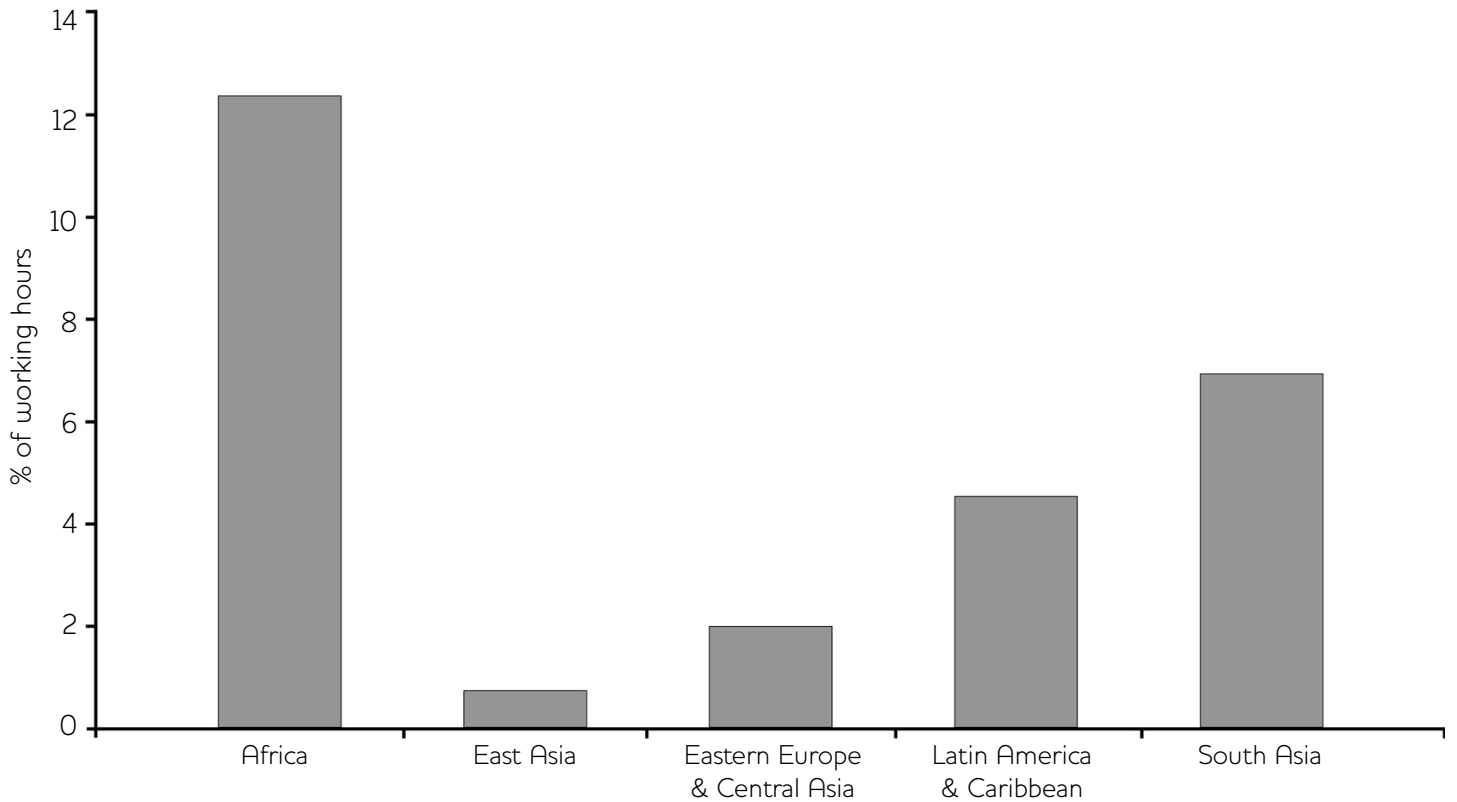

Source larossi (2009) using Enterprise Surveys from various years. 
sector has been most prominent in water, sanitation and transport, where it contributed above 50 per cent of capital investments in the sector in 2001-06. Private investment, on the other hand, accounted for over 75 per cent of capital investments in ICT over the same period (Biau et al. 2008; OECD 2010). Infrastructure financing in Africa, however, has been changing in recent years, and a new mix of sources - including increasingly private and innovative ones - is emerging.

Domestically, African governments could increase private savings and channel them to productive uses by facilitating the development of local capital markets. Instruments such as corporate bonds or government infrastructure bonds are limited to countries with sufficiently developed domestic bond markets. Other schemes such as sovereign wealth funds and resource-backed infrastructure financing are better tailored for resource-exporting countries.

Given the abundance of natural resources, African countries could tap carbon finance markets to finance low-carbon infrastructure. So far though, access to carbon credits by clean technology projects in emerging markets and developing countries has had mixed results across regions, with Africa lagging substantially behind.

African governments should also mobilise other domestic resources. Removing exemptions and strengthening tax administration would increase public tax revenues. In low-income countries, where the large informal sectors impede effective direct taxation, excises, value-added taxes and other indirect taxes could be relied upon. Post-conflict countries may consider utilising trade taxes and other simplified direct tax structures before a balance between indirect and direct taxes can be reached.

To mobilise private savings, formal financial institutions could offer long-term saving instruments, and governments could provide corresponding tax incentives. African governments could also remove regulatory barriers that discourage institutional investors such as pension funds from relying on long-term savings instruments. Moreover, they could help diversify capital markets by developing institutional frameworks encouraging Islamic finance institutions and private equity funds.
To unlock private infrastructure finance, Africa needs to increase the number of bankable projects. In addition to project preparation championed by multilateral development banks (MDBs) and donors, private investors should develop and bring projects to the market. In most African countries, however, this is constrained by the absence of relevant procurement processes, rules for handling unsolicited proposals or mechanisms for competitive bidding. In such an environment, the risk that private investors who bring forth proposals lose proprietorship is high. MDBs and the donor community should consider supporting the development of an enabling environment for project identification and development by private partners.

Fostering a regional approach to infrastructure is another source of infrastructure financing through efficiency gains. Indeed, Africa's geography demands a regional approach to regional infrastructure development to ensure efficiency in service provision and to maximise resources. The continent could save US $\$ 2$ billion a year in energy costs by utilising the existing regional power pools ${ }^{3}$ to their full potential (Foster and Briceño-Garmendia 2010).

Developing the continent's largely untapped hydropower potential through investments in regional infrastructure such as the Grand Inga Project would generate financial returns for Africa's power pools of 20-30 per cent, and as high as 120 per cent for the Southern African Power Pool. Similarly, developing a transnational highway network linking all capitals in subSaharan Africa could result in trade gains of up to US $\$ 250$ billion over 15 years (Buys et al. 2007). Developing regional hubs, particularly in maritime and air transport infrastructure, would also boost efficiency.

\section{Infrastructure, poverty reduction and the post-2015 agenda}

For the Africa region, steady progress on the MDGs has been made. Advances have been made in primary school enrolment, gender parity in primary school enrolment, the proportion of seats held by women in national parliament, and HIV/AIDS prevalence rates. In spite of this progress, Africa still faces the challenges of addressing pervasive income inequalities, the creation of decent jobs and access to health and sanitation services. 
In order for Africa to reap the rewards of its booming population and economic growth, its post-2015 MDG agenda must prioritise building skills for tomorrow's job market, fostering efficiency and accountability in services and building social and financial systems for inclusive growth. An inclusive economic growth agenda will provide wider access to economic opportunities (jobs) for Africans across the age, gender, regional and geographic divide. Investing in infrastructure (transport, energy, ICT, water and sanitation) will unlock the growth and development potential of the private sector and enhance community participation. It will improve skills for competitiveness and ensure that training better matches the opportunities and requirements of the local labour markets.

Despite its clear benefits for growth and poverty reduction, infrastructure spending is far below what is needed. To reduce poverty, the decline in infrastructure investment must be reversed. A significant increase in national, cross-border and regional infrastructure investment is needed to advance growth and reduce poverty in African countries. The United Nations Millennium Project estimates that between 2005 and 2015, sub-Saharan Africa countries' annual needs for infrastructure investment and maintenance equal 13 per cent of GDP. Indeed infrastructure makes valuable contributions to all MDGs. The many benefits of infrastructure have also been confirmed by the United Nations Millennium Project (2005), which advocates a major increase in basic infrastructure investments to help countries (especially in Africa) escape the poverty trap, and by the Commission for Africa Report (2005).

Infrastructure investment in water and sanitation improves social MDGs that inhibit poor people's access to health and education facilities.

Accordingly, the social MDGs (numbers 2-6) indicate the need to improve transport services and facilities, and to link investment in transport with those in health and education. For example, good roads and reliable transport and communication services are a key reason maternal mortality rates have fallen in many countries, and health investments provide only added benefits. Similarly the school attendance of poor children (mainly girls) - particularly in secondary education - is highly dependent on affordable transport services, with manageable distances and times from their homes. Green and sustainable infrastructure (solar, geothermal, wind and rail) all support the Sustainable Development Goals (SDGs) being proposed.

The links between infrastructure services, growth and social outcomes such as the MDGs operate through multiple channels. The delivery of services such as water, sanitation, transportation and energy directly benefit households and can dramatically improve welfare. In rural areas where most of the poor reside and where agriculture remains the main source of income, infrastructure (including transport) lowers the costs of inputs and facilitates access to credit, extension services and, most importantly, output market with better prices. It also facilitates the commercialisation of farm and non-farm activities and often leads to agricultural diversification from low-value food grains to more perishable high-value agricultural products as well as reducing post-harvest losses.

Infrastructure investment promotes rural wages, non-farm employment and migration, thereby reducing rural poverty. For example, improved road access helps farmers set up small rural non-farm businesses such as food processing and marketing enterprises, electronic shops,

transportation and trade, and restaurant services.

It has been widely recognised that the current MDGs focus excessively on the social aspect of the sustainable development agenda, neglecting the economic and environment ones. Current MDGs also de-emphasise productive sectors, including infrastructure. They are therefore not encouraging structural transformation. Without productive capacity, including infrastructure, the current MDGs achievements may not be sustained. The post-2015 framework could rebalance focus towards more productive indicators. The AfDB's infrastructure index could be useful for monitoring progress.

The United Nations Economic Commission for Africa (UNECA) and the African Union Commission (AUC) carried out an electronic survey of 112 representatives of governments, NGOs and civil society in 32 African countries to reflect realities on the ground on the Post-2015 Development Agenda (AUC et al. 2012). The perspective of the respondents was that the MDGs should be amended post-2015 because as now constituted they have limited focus on 


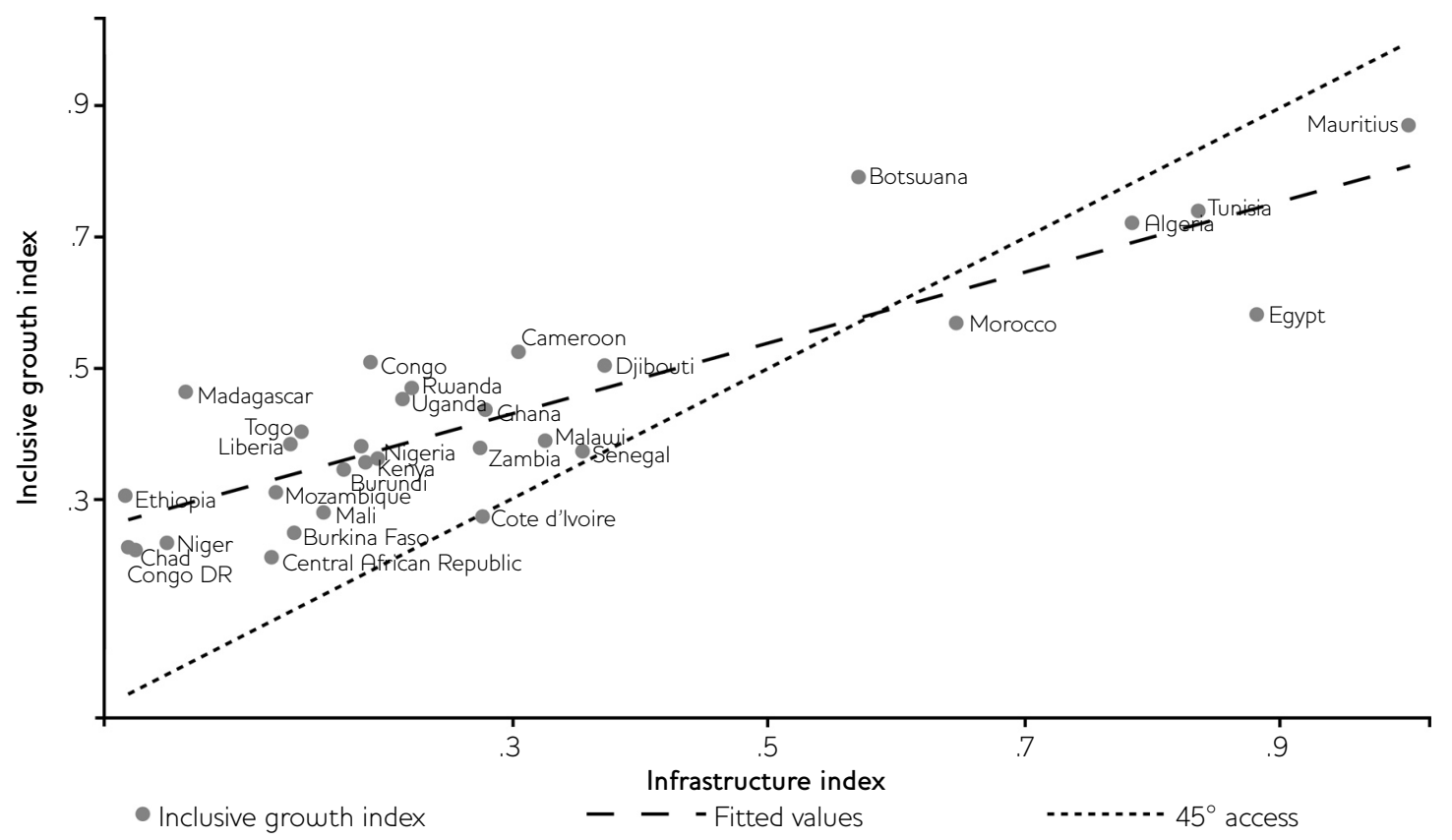

Source AfDB (2013).

economic growth and transformation, thereby excluding the role of factors such as infrastructure. The electronic survey results show that 85 per cent supported including infrastructure in post-2015, along with food security, governance and peace and security.

The post-2015 MDG framework will be essential for achieving results as agreed at the Rio +20 summit, which brings together the social, environmental and economic dimensions included in sustainable development. The post2015 agenda must seek to promote African resilience by addressing associated vulnerabilities. Economic activity should reflect efforts to adapt to and mitigate the effects of climate change, as well as to move towards a lowcarbon growth path. The post-2015 framework should be framed around a few core objectives, aimed at solving a number of big global problems simultaneously. It might involve a combination of existing MDGs on development and poverty plus some other objectives around human rights, governance and wellbeing.

\section{The role of the African Development Bank}

Given the centrality of inclusive growth in the AfDB's Ten-Year Strategy 2013-2022, it is logical to monitor the progress of inclusive growth in regional member countries. The AfDB is developing the African Inclusive Growth Index (AIGI) as a first attempt to quantify the dimensions of inclusive growth outlined with the objective of providing a comprehensive measure of a country's progress over time. The AIGI builds on the Human Development Index used by the United Nations Development Programme (UNDP) and adds the following: income inequality, economic sophistication, voice and accountability, and social equity.

One way in which the AfDB is looking at improving the Country Policy and Institutional Assessment (CPIA) of regional member countries is the incorporation of infrastructure as one of its components. This arises from the fact that a significant amount of exclusion in distribution of wealth, opportunities and voice arises from spatial or geographic differences, often due to bad infrastructure. To see how this works, the measure of the AfDB's inclusive growth, which does not include infrastructure at all, is highly and significantly correlated with the AfDB's infrastructure index. The better a country's infrastructure, the greater the potential for inclusion, as shown in Figure 4. 
In addition to financing infrastructure and supporting capacity building on the continent, MDBs such as the African Development Bank have refined their instruments to enhance involvement in areas of comparative advantage and unlock restrictions to individual countries' borrowing. This includes the provision of blended financing packages and risk management instruments to catalyse private finance, building capacity and country systems, and brokering complex regional projects.

Indeed, the AfDB is involved in financing infrastructure and catalysing funds through traditional and innovative methods for both the public and private sectors in order to facilitate private sector development. The AfDB is also working closely with the African Union through the recently launched Programme for Infrastructure Development for Africa (PIDA) and is developing a road map for the execution of a priority set of regional integration infrastructure projects.

For the period 2008-12, the AfDB's cumulative financing for infrastructure projects and programmes amounted to UA11.3 billion (US\$17.4 billion), which represents about half of

\section{Notes}

1 Statistics are drawn from the AICD database (Foster and Briceño-Garmendia 2010), which covers 24 African countries, and from the African Development Bank Statistics Department (AfDB 2011).

2 This figure pertains to an investment and maintenance programme to develop the following infrastructure in sub-Saharan Africa: (1) 7,000 megawatts a year of new power generation capacity (about half through multipurpose dams); (2) Cross-border transmission lines with a capacity of 22,000 megawatts; (3) Fibre optic cable to complete the intraregional fibre optic backbone network and continental submarine cable loop; (4) Good quality road network to interconnect capitals,

\section{References}

AfDB (2013) Performance Based Allocation (PBA's) as a Vehicle for Inclusive Growth, Tunis-Belvedere: Development Research Department (EDRE), African Development Bank

AfDB (2011) Infrastructure Database, Tunis-

Belvedere: African Development Bank its commitments to all sectors. ${ }^{4}$ The two principal beneficiary subsectors for the period were transportation (42.5 per cent) and energy (44.1 per cent) followed by water and sanitation (12.3 per cent) and ICT (1.1 per cent). For 2012, UA1.8 billion (US $\$ 2.8$ billion) was allocated to the infrastructure sector, which is almost half of the Bank Group approvals to all sectors. Of this, energy received about half of the financing. The AfDB seeks to contribute to the development of sound domestic debt markets in Africa through the creation of the African Domestic Bond Fund.

MDBs play a critical role in assisting countries to access special envelopes of financing, such as climate finance. For example, the donor-funded Clean Technology Fund claims it will leverage at least five times its value in clean energy solutions, including energy efficiency, renewable energy, and sustainable transport investments. Africa's perspective must be taken into account when decisions on disbursements of global funds for climate-change adaptation and mitigation are made. To help facilitate access to these funds, the AfDB is setting up the Africa Green Fund to receive and manage resources to address climate change on the continent.

ports, border crossings and secondary cities; (5) All-season roads to access high-value agricultural land; (6) Irrigation infrastructure to more than double Africa's irrigated area;

(7) Infrastructure to meet the MDGs for water and sanitation; (8) Electricity network to raise household electrification rates by 10 percentage points; and (9) Network to provide global systems mobile voice signal and public access broadband to 100 per cent of the population (Foster and Briceño-Garmendia 2010).

3 Power pools are regional interconnected electricity grids to enhance cross-border electricity trade and foster regional economic integration.

4 UA is Unit of Accounts used by the AfDB. $1 \mathrm{UA}=\$ 0.15$ (June 2013).

Anyanwu, J.C. and Erhijakpor, A.E.O. (2009)

'The Impact of Road Infrastructure on Poverty Reduction in Africa', in Thomas W. Beasley (ed.), Poverty in Africa, New York: Nova Science Publishers, Inc.: 1-40

AUC; UNECA; AfDB and UNDP (2012) Assessing Progress in Africa toward the Millennium 
Development Goals, MDG Report 2012, www.undp.org/content/dam/undp/library/ MDG/english/MDG\%20Regional\%20Reports/ Africa/MDG\%20Report2012_ENG.pdf\%20 (final).pdf (accessed 13 June 2013)

Biau, C.; Dakou, K. and Homma, T. (2008) 'How to Increase Sound Private Investment in Africa's Road Infrastructure: Building on Country Successes and OECD Policy Tools', NEPAD-OECD Africa Investment Initiative, Experts Roundtable, December

Buys, P.; Deichmann, U.; Meisner, C.; That, T.T. and Wheeler, D. (2007) Country Stakes in Climate Change Negotiations: Two Dimensions of Vulnerability, Policy Research Working Paper 4,300, Washington DC: World Bank

Commission for Africa Report (2005) www.commissionforafrica.info/2005-report (accessed 1 July 2013)
Escribano, Alvaro; Guasch, J. Luis and Pena, Jorge (2008) Impact of Infrastructure Constraints on Firm Productivity in Africa, Working Paper 9, Africa Infrastructure Sector Diagnostic, Washington DC: World Bank

Foster, Vivien and Briceño-Garmendia, Cecilia (eds) (2010) Africa's Infrastructure: A Time for Transformation, Africa Infrastructure Country Diagnostic (AICD), Washington DC:

International Bank for Reconstruction and Development/World Bank

Iarossi (2009) Benchmarking Africa's Costs and Competitiveness, Africa Competitiveness Report Geneva: World Economic Forum and AfDB

OECD (2010) 'Infrastructure in Africa', Policy Brief (October) NEPAD_OECD Africa Investment Initiative

UN (2011) The Millennium Development Goals Report 2011, New York: United Nations 